\title{
STATICS AND KINEMATICS OF SEMIRIGID STEEL FRAMES UNDER SEISMIC ACTION
}

\author{
Aliz Mathe ${ }^{a_{*}}$, Al. Cătărig ${ }^{a}$, Ilinca Moldovan ${ }^{a}$ \\ ${ }^{a}$ Technical University of Cluj-Napoca, Faculty of Civil Engineering, Structural Mechanics Department, 15 Constantin Daicoviciu \\ Str., Cluj - Napoca, 400020, Romania
}

Received: 03.09.2015 / Accepted: 10.10.2015 / Revised: 18.11.2015 / Available online: 15.12.2015

DOI: 10.1515/jaes-2015-0022

KEY WORDS: steel frames, seismic action, semirigid, accelerograms

\begin{abstract}
:
Intended contribution emphasizes the statics and kinematics of semi-rigid steel frames seismically acted upon. The dynamic model of analyzed structures consists of multi degree of freedom systems with lumped masses located at floor levels. The dynamic degrees of freedom are the lateral seismically induced floor displacements. A cyclic behavior of semi-rigid beam - column connections associated with the four parameters analytical bending moment $M$ - relative rotation $\theta_{r}$ is considered. Time history seismic analyses are performed on multi-story steel planar frames equipped with several top and seat and web angle beam - column connections acted upon by recorded seismic actions. The computed numerical results refer to the contrary static and effects of semi-rigidity: the increase in lateral floor displacements accompanied by a decrease in the seismic base shear force. Relevant comments are drawn.
\end{abstract}

\section{INTRODUCTION}

The semi-rigidity of beam to column connections of multi-story steel frames is a concept that theoretically - has been largely developed, while practically it is based on a huge set of laboratory investigations.

The results of theoretical and laboratory investigations lead to a unanimously accepted status of semi-rigid frames: the status of a distinct category of structures placed between the bending moment resisting frames and hinged frames (European Commission-EUR 18366, 1998), (EN 1993-1-1, 2004), (FEMA-350, 2000), (Máthé, 2009; Cătărig et al., 2009, 2010). What may just another set of analytical results bring or add to the existing ones? One answer to this question is given in this present

\footnotetext{
* Corresponding author. e-mail: aliz.mathe@mecon.utcluj.ro
}

contribution: the effect of semi-rigidity includes two contradictory aspects of seismic behavior.

On one hand, the semi-rigidity allows for larger floor level lateral displacements due to an increased flexibility at the global (structural) level. On the other hand, the greater lateral flexibility will induced smaller seismic base shear forces. A reduced base shear force will lead in its turn - to reduced statically equivalent seismic forces and, therefore, to smaller seismically induced lateral displacements (Máthé \& Cătărig, 2015). This is where the kinematics and statics of semi-rigid steel frames encounter into above mentioned contradiction regarding the seismic behavior. Indeed, too many times the seismic effect on multi-story structures is equated to the lateral floor level displacements (Prodan et al., 2010; Mathe \& Blaga, 2010) while other seismically induced states as static and energy states are omitted (Lădar, 2013). 
Even the seismic mitigation is, many times, exclusively assessed by the reduction in lateral displacements, overlooking that the increase in seismic base shear force (as the result of high lateral rigidity) leads to the increase in the same lateral displacements that have been the objective of seismic mitigation.

Therefore, the real effect of semi-rigidity has to be asses by considering simultaneously both - static and kinematic - aspects of the seismically induced mechanical state of the structure. This is, actually, the objective of proposed contribution: a parallel and simultaneous assessment of the effect of seismic behavior of multi-story steel structures with decreased lateral stiffness associated to semi-rigidity at beam - column connection level.

The performed seismic analyses are of time-history type using recorded scaled accelerograms. The seismic analyses are conducted on several multistory steel frames equipped with semi-rigid beam to column connection of top and seat and web angle (TSW) connections. The analyzed structures have been designed to fulfill the ultimate and serviceability limit states according to the current design provisions (P100 - 1/2013, 2013). The dynamic model of analyzed structures is the common multi-degree-of-freedom-model associated with the matriceal differential equation

$$
\boldsymbol{M u}(t)+\boldsymbol{C} \dot{\boldsymbol{u}}(t)+\boldsymbol{R} \ddot{\boldsymbol{u}}(t)=-\boldsymbol{m} \ddot{\boldsymbol{u}}_{g}(t)
$$

where:

$$
\begin{aligned}
& \boldsymbol{M} \text { is the ( } n \times n) \text { inertia (mass) matrix, } \\
& \boldsymbol{C} \text { is the (nxn) damping matrix, } \\
& \boldsymbol{R} \text { is the ( } n \times n) \text { stiffness matrix, } \\
& \mathbf{m} \text { is the } \mathrm{n} \text { mass vector. }
\end{aligned}
$$

The kinematic $n$ vectors $\boldsymbol{u}, \dot{\boldsymbol{u}}, \ddot{\boldsymbol{u}}$ represent the (lateral floor) displacements, velocities and accelerations, respectively.

The inherent damping state is considered of the Rayleigh linear viscous type] associated to the damping matrix $\boldsymbol{C}$ given by

$$
\boldsymbol{C}=\alpha \boldsymbol{M}+\beta \boldsymbol{R}
$$

A detailed analysis of linear viscous damping matrix $\boldsymbol{C}$ including the orthogonality of eigen vectors with respect $C$ is given in (Chopra, A.K., Goel, R.K., 2001). In what has been considered in the present contribution the orthogonality of eigen vectors $\boldsymbol{\varphi}_{j}$ is considered in the form

$$
\boldsymbol{\varphi}_{j}^{T} \cdot \boldsymbol{C} \cdot \boldsymbol{\varphi}_{j}=\mathbf{0}
$$

Several TSW connections are considered such that the ultimate bending capacity of the beam - column connection varies from $35 \%$ to $80 \%$ of the beam in its current cross section. The several beam to column TSW connections considered in the performed analyses make up a set of six different states concerning the initial stiffness. The rigidly connected structure is also considered as the reference structure.

Analytical models of semi-rigidity is based on the Richard - Abbott four parameters model (Richard \& Abbott, 1975,Kishi \& Chen, 1990) that has been updated to required cyclic behavior specific to seismically induced vibrations.

Selected seismic actions are Northridge 1994 and Kobe 1995 recorded earthquakes. The analyses are performed entirely (overall structural behavior and the behavior of the semirigid connections) in the elastic domain by the use of SEISMOSTRUCT computer program (seismosoft.com/seismostruct).

Computed parameters are the floor lateral, base shear seismic force and the periods of the fundamental natural modes of vibrations. The results are presented in a comparative manner, commented and relevant conclusions are inferred.

\section{ANALYZED STRUCTURES. SEMIRIGID CONNECTIONS. SEISMIC ACTIONS}

A set of multistory steel planar semi-rigidly connected frames (of 5, 9 and 12 stories respectively) acted upon by three recorded seismic actions (Vrancea 77, Northridge 1994 and Kobe 1995) have been analyzed. The 5 levels 3 spans structure together the cross sections of its members are given in figure 1 .

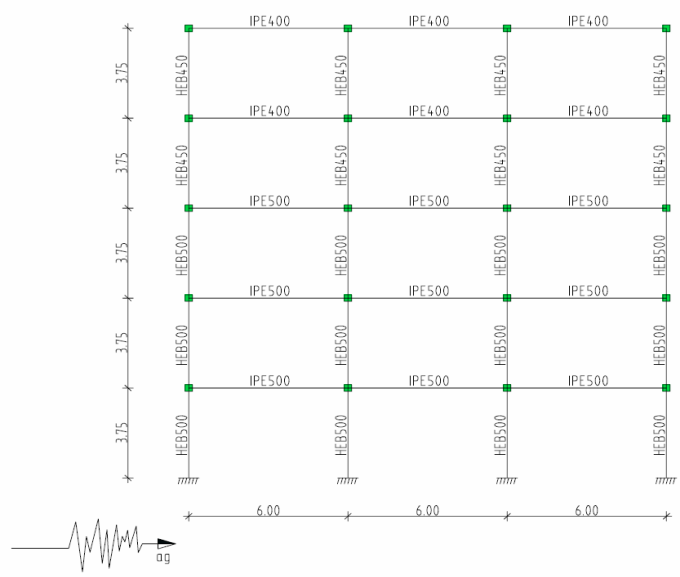

Figure 1. TSW semi-rigid beam to column connection 
The semi-rigid beam to column connections are considered in six different cases from the point of view of initial stiffness $R_{c}$ of the connection. The initial stiffness of the connection is involved by the Kishi - Chen analytical $M-\theta_{r}$ (bending moment relative rotation) model (4) of the semi-rigid connection.

$$
\theta_{r}=\frac{M}{R_{i} \sqrt[n]{1-\left(\frac{M}{M_{p}}\right)^{n}}}
$$

The values of various geometrical parameters corresponding to the TSW beam - column connection are presented in table 1 .

\begin{tabular}{|c|c|c|c|c|c|c|}
\hline & $S R-$ & $S R-$ & $S R-$ & $S R-$ & $S R-$ & $S R-$ \\
& 1 & 2 & 3 & 4 & 5 & 6 \\
\hline$t_{t} ; t_{s}$ & 10 & 12 & 13 & 14 & 15 & 15 \\
\hline$t_{w}$ & 10 & 10 & 11 & 12 & 14 & 15 \\
\hline$l_{t} ; l_{s}$ & 170 & 210 & 230 & 250 & 230 & 250 \\
\hline$l_{w}$ & 150 & 200 & 260 & 230 & 230 & 250 \\
\hline$g_{t} ; g_{s}$ & 60 & 60 & 60 & 60 & 60 & 60 \\
\hline$g_{w}$ & 60 & 60 & 60 & 60 & 60 & 60 \\
\hline
\end{tabular}

Table 1. Beam-Columns connection's parameters

The six values of the initial stiffness $\mathrm{R}_{\mathrm{i}}$ considered in the present contribution are:

$$
\begin{array}{lll}
\text { 1. } R_{i}=5 \mathrm{x} R_{g} & \text { 2. } R_{i}=10 \mathrm{x} R_{g} & \text { 3. } R_{i}=15 \mathrm{x} R_{g} \\
\text { 4. } R_{i}=20 \mathrm{x} R_{g} & \text { 5. } R_{i}=25 \mathrm{x} R_{g} & \text { 6. } R_{i}=30 \mathrm{x} R_{g}
\end{array}
$$
where:

$R_{g}$ is the relative bending stiffness (EI/l) of the beam. The six above values of initial stiffness $R_{c}$ will be referred as $S R-1, \ldots$, $S R-6$. It can be immediately noted that SR-1 state is the most flexible one, while SR-6 is the most rigid state of the TSW connections. The values of parameters involved in the Kishi - Chen model corresponding to a hot rolled beam profile IPE400 are given in Table 2 for each stiffness state $S R$.

\begin{tabular}{|c|c|c|c|}
\hline & $R_{i}(\mathrm{kNm} / \mathrm{rad})$ & $M_{u}(\mathrm{kNm})$ & $n$ \\
\hline$S R-1$ & 40510 & 142 & 1,201 \\
\hline$S R-2$ & 80690 & 227 & 1,066 \\
\hline$S R-3$ & 121700 & 304 & 0,994 \\
\hline$S R-4$ & 163800 & 351 & 0,900 \\
\hline$S R-5$ & 208700 & 390 & 0,827 \\
\hline$S R-6$ & 243500 & 441 & 0,825 \\
\hline
\end{tabular}

Table 2. Parameters value to IPE400 beam profile
The Kishi - Chen analytical model, associated to a monotonically behavior of the connection, is specifically processed and transformed into a cyclical form appropriate to seismic behavior of the structure (Kishi, N., Chen W.F., 1990). Performed analyses are conducted in SEISMOSTRUCT computer (seismosoft.com/ seismostruct). Elastic behavior of the structure and of the semi-rigid connections is assumed.

\section{NUMERICAL RESULTS}

To emphasize the influence of semi-rigidity upon the seismic response, two behavioral parameters have been selected out of a larger set that have been computed: top lateral displacements and seismic base shear force. The variations in time of the two parameters are presented graphically in a comparative manner (figure 3 and figure 4).

Every state of stiffness conferred by the semi-rigidity of the connections is plotted versus the results of the reference structure (rigidly connected).

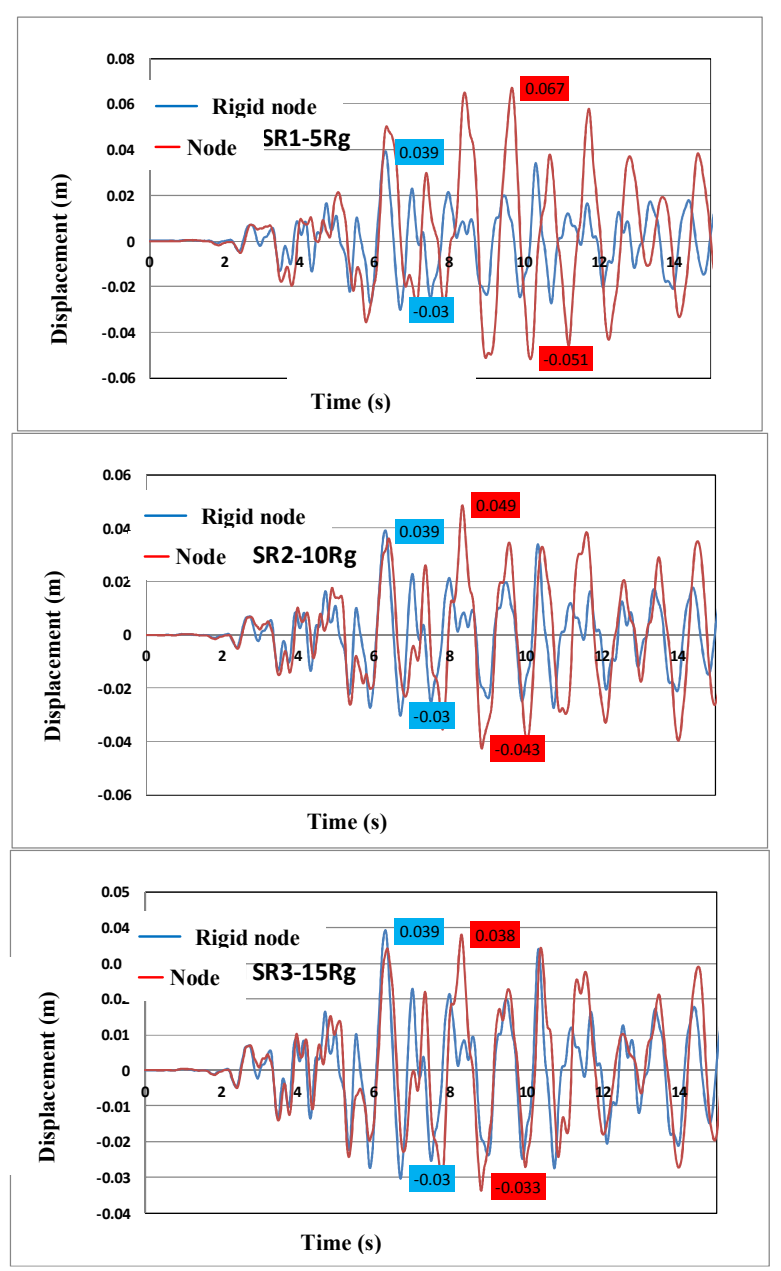




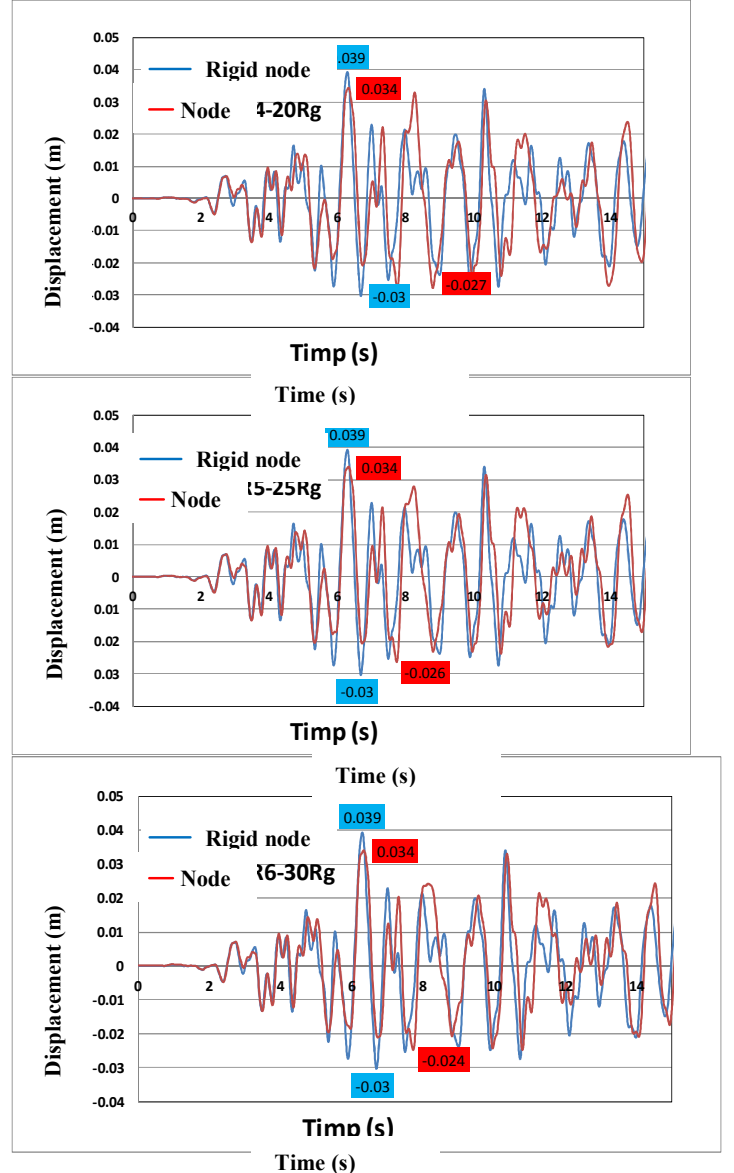

Figure 3. Top lateral displacements

Numerical results associated to seismic base shear force are presented for the same structure (5 levels, 3 spans) and the same seismic action (Kobe, 1995). Again, the results are related such that every stiffness state faces the reference structure.

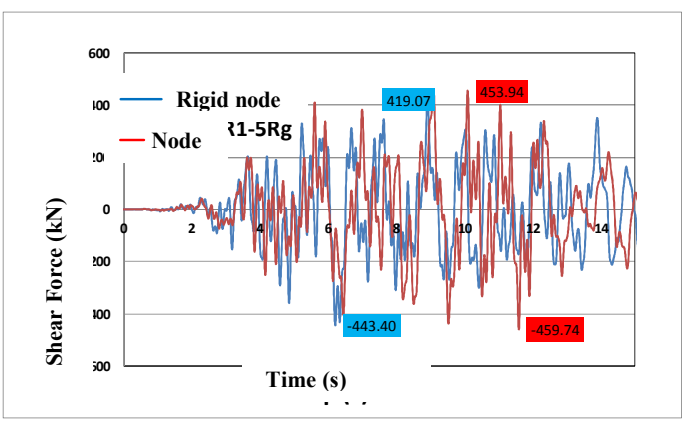

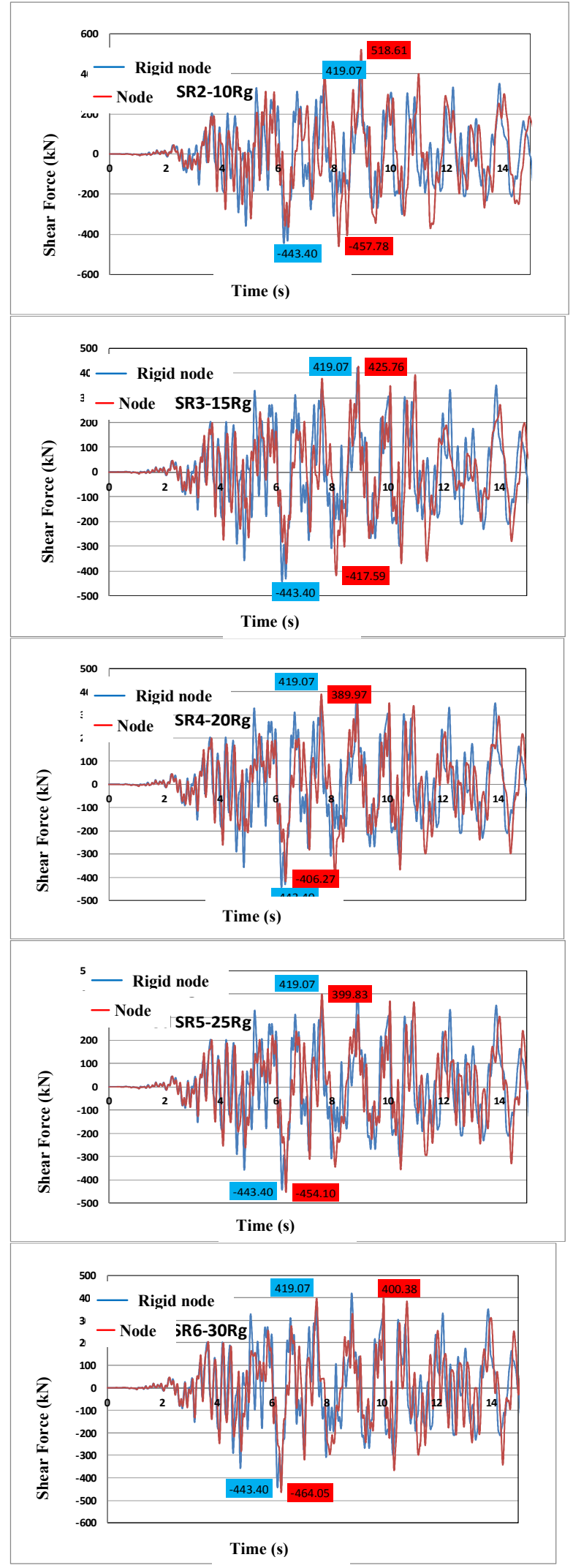

Figure 4. Seismic base shear force 
Other important parameters associated to seismic behavior are the eigen periods of natural vibration modes.

In spite of being independent of the seismic action, the periods of natural modes strongly affect the seismic response. Natural periods (mainly fundamental period $T_{1}$ ) have to be related to the predominant period $T_{c}$ of applied earthquake (table $3)$.

\begin{tabular}{|c|c|c|}
\hline & $a_{g}\left(\mathrm{~m} / \mathrm{s}^{2}\right)$ & $T_{c}(s)$ \\
\hline Kobe 1995 & 1,962 & 0,16 \\
\hline Northridge 1994 & 1,961 & 0,26 \\
\hline Vrancea 77 & 1,950 & 1,16 \\
\hline
\end{tabular}

Table 3. Earthquake characteristics

The periods of the natural modes of vibration of the 5 level structure are presented in table 4 for each case of stiffness level.

\begin{tabular}{|l|c|c|c|c|c|}
\hline & 1 & 2 & 3 & 4 & 5 \\
\hline$S R-1$ & 1,011 & 0,323 & 0,152 & 0,090 & 0,063 \\
\hline$S R-2$ & 0,912 & 0,300 & 0,146 & 0,089 & 0,063 \\
\hline$S R-3$ & 0,870 & 0,290 & 0,143 & 0,088 & 0,063 \\
\hline$S R-4$ & 0,849 & 0,284 & 0,141 & 0,088 & 0,063 \\
\hline$S R-5$ & 0,836 & 0,280 & 0,140 & 0,088 & 0,063 \\
\hline SR-6 & 0,825 & 0,278 & 0,139 & 0,087 & 0,063 \\
\hline Rigid & 0,779 & 0,265 & 0,135 & 0,086 & 0,062 \\
\hline
\end{tabular}

Table 4. The periods of vibrations

\section{CONCLUSIONS}

Computed and presented numerical results constitute a clear picture of the influence of semi-rigidity at the beam - column level upon the seismic behavior of multi-story steel structures.

The three relevant parameters associated to a seismically induced vibratory state (top lateral displacements, seismic base shear force and periods of natural modes of vibration) emphasize the dependency of seismic response on the semi-rigidity state. While the reduction of lateral displacements with the increase in lateral overall stiffness state is generally expected, the variation of seismic base shear force has to be carefully considered.

A higher lateral rigidity induces larger seismic base shear forces, therefore, larger values of stress resultants (mainly bending moments).

\section{REFERENCES}

European Commission-EUR 18366, Promotion of plastic design for steel and composite cross-sections: new required conditions in Eurocodes 3 şi 4, practical tools for designers. Technical steel research series, Luxembourg, 1998.

EN 1993-1-1, Design of steel structures-General rules and rules for buildings. CEN, European Committee for Standardization, 2004.

FEMA-350, Recommended seismic design criteria for new steel moment-frame buildings. Report No. FEMA-350, SAC Joint Venture, Federal Emergency Management Agency, Washington, DC, 2000.

Máthé, Aliz, Analiza elastică geometric neliniară a structurilor metalice cu conexiuni flexibile. (Nonlinear geometrical elastic analysis of semirigid connections). Phd. Thesis, Technical University, Cluj-Napoca, 2009.

Cătărig, A., Alexa, P., Kopenetz, L., Mathe, Aliz, Lădar, Ioana, Geomatrically Nonlinear Analysis of Semirigid Steel Struictures. International Seminar of IASS Polish Chapter, XV Jubilee LSCE 2009, Warsaw, 2009, pag.29-32.

Cătărig, A., Mathe, Aliz, Chira, N., Popa, Anca, Steel Structures with Semi-Rigid Connections. Analele Universitătii din Oradea, Fascicula Construcții şi Instalații hidroedilitare, (University of Oradea Annals, Journal of Civil engineering and installations, Vol. XIII-2, 2010, pag.21-32.

Máthé, Aliz, Cătărig, Al., Răspunsul seismic al structurilor metalice multietajate semirigide. (Seismic response of multystorey steel structures with semirigid connections). A 14-a Conferinţă Națională de Construcții metalice, ( The 14-th National Conference on Steel Structures) Cluj-Napoca, 2015.

Prodan, O., Lădar, Ioana, Alexa, P., Seismic Performances of Steel Structures with Supplementar Damping. Numerical Studies. $14^{\text {th }}$ European Conference on Earthquake Engineering, Ohrid, Republic of Macedonia, 2010, pp.476-482.

Mathe, A. Blaga, F., Semirigidity contribution to seismic behavior of steel structures. Lightweight structures in Civil Engineering, XVI, International Seminar of IASS-Polish Chapter Varsovia, 2010, Vol. 16, pg. 63-69, Micro-PublisherConsultant-Project.

Lădar, Ioana, Răspunsul seismic al structurilor metalica. $O$ abordare energetică. ( Seismic response on steel structures. An energetic approach). Phd. Thesis, Technical University, ClujNapoca, 2013.

* * * P100 - 1/2013, Cod de proiectare seismică. Partea I Prevederi de proiectare pentru clădiri.

Chopra, A.K., Goel, R.K., A Modal Pushover Analysis Procedure to Estimate Seismic Demands for Buildings: Theory and Preliminary evaluation. Report no. PEER 2001/3, Pacific Earthquake Engineering Research Centre, University of California, Berkeley, C. A., 2001. 
Richard, R.M., Abbott, B.J., Versatile elastic-plastic stress-strain formula. Journal of the Engineering Mechanics, ASCE, 101(4), 1975, pp.511-515.

Kishi, N., Chen W.F., Moment-rotation relations of semirigid connections with angles. Journal of Structural Engineering, ASCE, 116(7), 1813-1834, 1990.

www.seismosoft.com/seismostruct, viewed at 10.10.2015. 